\title{
Simulation of concentrations harmful compounds from main ship's propulsion engine cooperating with a fixed pitch propeller in dynamic states
}

The article presents a mathematical model of a marine propulsion system and a computer program based on the LabVIEW environment. For a purpose of model construction, a ship's hull resistance was identified and an approximation equations of the Wageningen institute for ship propellers were used. The ship's motion equations were used to build the propulsion system model. On the basis of conducted tests of Sulzer 6AL20 / 24 marine engine, a map of concentrations harmful compounds was created in various load state and transferred to a computer program.

Key words: simulation, modelling, emission, marine diesel engine

\section{Introduction}

In real operating conditions of vessels, almost always on a propulsion system and a ship's hull affect external extortion, which directly or indirectly cause smaller or larger changes in operation of a propulsion system. We distinguish here the extortion from a ship's crew and determined by weather conditions and a change of sail area.

The first type of extortion includes changes:

- a speed of vessel,

- a sail direction by overriding an engine,

- a propeller pitch,

- a position of a rudder blade.

As result of these interactions are a change of an engine load, and connected with it, a crankshaft speed, a propeller force and a ship's speed. Most of these extortions take place on a roadstead and in port areas close to human agglomerations. As a result of a dynamic load shift, there is a change in a emission of harmful compounds into the atmosphere, which on a scale of ship's movement in a port area has a significant impact on residents and human agglomerations in coastal regions.

In addition to seagoing vessels, which leave a port area and head towards an open sea, we distinguish special units in a form of tugs, dredgers, pilot vessels, fishing vessels, trawlers or other boats whose power plants operate in dynamic load states. The work of these vessels takes place even around the clock. Tugboats assist in mooring and unmooring merchant ship, or dredgers carrying out work deepening port areas using this day in the evening, where traffic in a port is limited.

The first part of the article presents ship's operation modes in port regions. Criteria for particular modes of operation of ships sailing in this area have been defined. The concept of land supply is also presented as one of the ways to reduce the emission of harmful compounds into the atmosphere by ships. The concept of "On-shore Power Supply" (OPS) has also been defined as one of the ways to reduce the emission of harmful compounds into the atmosphere by ships.

The second part of the article presents the model of a drive system, which has been implemented in the Labview graphical programming environment [2].

\section{Dynamic states of work in port areas}

Emission of harmful compounds depends mainly on a load of a propulsion system. The power demand is related to manoeuvring a vessel. For sea-going vessels, there is a direct relationship between a power generated by a propulsion system and a ship's speed. For special units such as tugs, dredgers, ferries, whose main mode of operation are manoeuvres (e.g. acceleration, deceleration, mooring work, circulations, etc.), the relationship between power and ship's speed is not the same. As other modes of work in port areas, we can distinguish a berth at a wharf and the mode of using a land supply so-called "On-shore Power Supply" (OPS).

The speed and position of a vessel depends mainly on the operating mode of a ship. Criteria for individual work modes are presented in table no. 1. The Automatic Identification System (AIS) system is an especially useful tool when determining the speed of a ship, which provides automatic data exchange, which helps to avoid collisions between vessels and identifies a ship for shore-based traffic surveillance systems Vessel Traffic Service (VTS).

Table 1. Criteria defining ship operation modes [4]

\begin{tabular}{|c|l|}
\hline Operating mode & \multicolumn{1}{|c|}{ Criterion } \\
\hline Manoeuvring & $\begin{array}{l}\text { A ship carries out manoeuvres for mooring / } \\
\text { unmooring. }\end{array}$ \\
\hline Hotelling & $\begin{array}{l}\text { A ship stands at a wharf to rebuild a readi- } \\
\text { ness for the voyage. }\end{array}$ \\
\hline Cruise & A ship on a way. \\
\hline OPS & $\begin{array}{l}\text { Ship's operating mode, which aims to reduce } \\
\text { the emission of harmful compounds into the } \\
\text { atmosphere. }\end{array}$ \\
\hline
\end{tabular}

Figure 1 presents sample data of ship's traffic in Swedish city - Göteborg. At an entrance or exit of a port it is necessary to perform manoeuvres by ships. Therefore, in port areas, regions are defined, which are applied to port maps as a manoeuvring region e.g. in a form of turning basins. In these areas it is assumed that ships reduce their speed, accelerate or slow down. In contrast to ships standing at a wharf and using power generators, from ships carrying out loading or unloading operations with a exception of their own power supply, the concept of "On-shore Power Supply" (OPS) has been introduced. 
The "On-shore Power Supply" is a region where a ship can completely shut off all its marine engines. OPS is also known as:

- Coldironing system.

- Alternative Maritime Power (AMP).

- Shoreside electricity.

- Shore power.

The main goal of OPS is to reduce the emission of toxic compounds (mainly greenhouse gases - GHG) in the port areas. In addition, thanks to this, it can provide energy savings and economic benefits for ship owners.

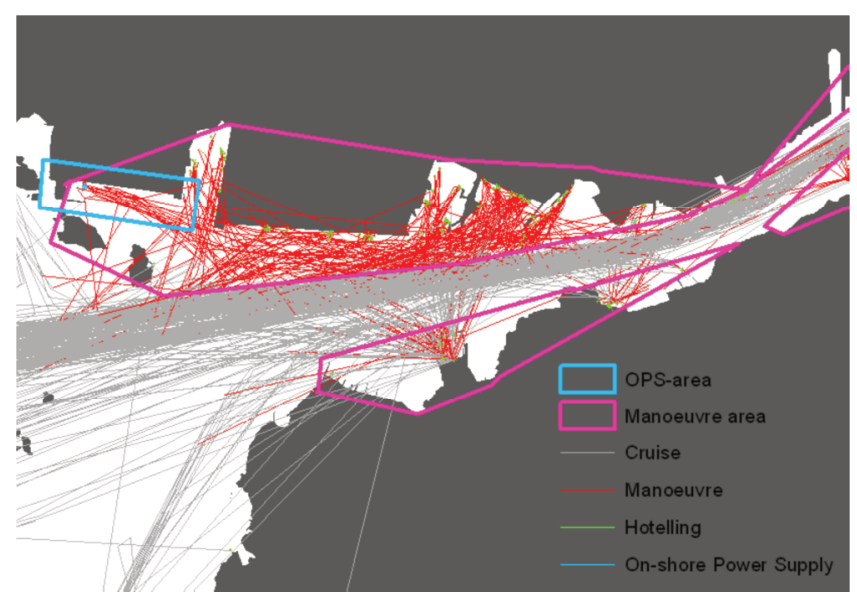

Fig. 1. Ship mode of operation in Swedish city - Göteborg [4]

\section{Research facility}

In the process of modelling the propulsion system, data obtained as a result of empirical research on a SULZER laboratory type 6AL20/24 engine were used [6]. The engine is a linear, non-reversible, water-cooled, 4-stroke diesel engine with direct fuel injection, turbocharging and charge air cooling (Fig. 2). Technical data of the engine are shown in table no. 2 .

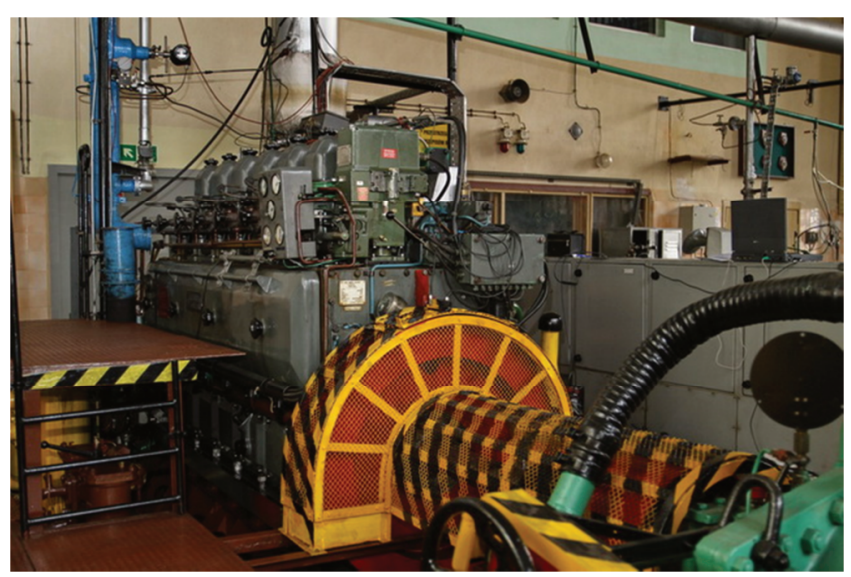

Fig. 2. Laboratory engine SULZER 6AL20/24 [8]

The main purpose of the work [6] was to prepare universal characteristics unit emissions of toxic compounds. An exemplary characteristic is shown in Fig. 3. In the plot of creating the characteristics, tests of concentrations of harmful compounds were carried out using the HEXIBA MEXA - 9130D exhaust gas analyser. The obtained data has been filtered out from disturbances and from measuring errors. Values of average concentrations of harmful compounds emitted were obtained using the formula:

$$
\mathrm{A}_{\mathrm{SA}}=\frac{1}{\mathrm{l}_{\mathrm{i}}} \sum_{\mathrm{i}=1}^{\mathrm{l}_{\mathrm{i}}} \mathrm{A}_{\mathrm{i}}
$$

where: $\mathrm{A}_{\mathrm{SA}}$ - arithmetic average, $\mathrm{A}_{\mathrm{i}}$ - result of a measurement, $1_{i}-$ number of measurements.

Table 2. Technical data of Sulzer 6AL20/24 engine [6]

\begin{tabular}{|l|c|}
\hline The number of cylinders & $\mathrm{i}=6$ \\
\hline Nominal power & $\mathrm{P}_{\mathrm{nom}}=420 \mathrm{~kW}$ \\
\hline Nominal speed & $\mathrm{n}_{\text {nom }}=750 \mathrm{~min}^{-1}$ \\
\hline Idle speed & $\mathrm{n}_{\mathrm{BL}}=350 \mathrm{~min}^{-1}$ \\
\hline The diameter of the cylinder & $\mathrm{D}=200 \mathrm{~mm}$ \\
\hline Piston stroke & $\mathrm{S}=240 \mathrm{~mm}$ \\
\hline Compression & $\varepsilon=12.7$ \\
\hline Engine stroke volume & $\mathrm{V}_{\mathrm{ss}}=45.2 \mathrm{dm}^{3}$ \\
\hline Average speed of the piston & $\mathrm{c}_{\mathrm{sr}}=6 \frac{\mathrm{m}}{\mathrm{s}}$ \\
\hline Cylinders work order & $1-4-2-6-3-5$ \\
\hline Maximum combustion pressure & $\mathrm{p}_{\mathrm{max}}=10.5-11.0 \mathrm{MPa}$ \\
\hline Fuel injection pressure & $\mathrm{p}_{\mathrm{w}}=24.5 \mathrm{MPa}$ \\
\hline Individual fuel consumption & $\mathrm{g}_{\mathrm{e}}=212 \frac{\mathrm{g}}{\mathrm{kW} \cdot \mathrm{h}}$ \\
\hline Number of valves per cylinder & $\mathrm{z}=4$ \\
\hline Type of start-up & pneumatic, compressed air \\
\hline
\end{tabular}

Based on the characteristics (Fig. 3), an emission map was prepared, and used in the simulation of ship's propulsion model (Fig. 4).

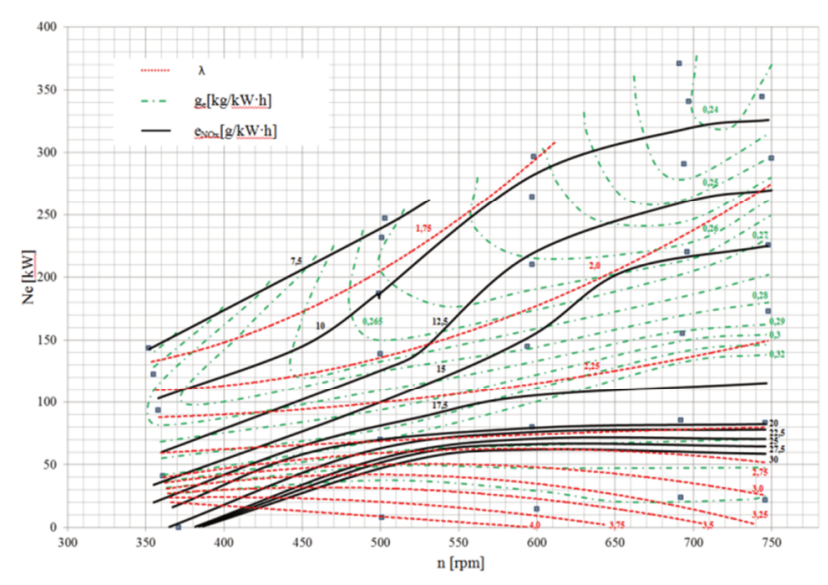

Fig. 3. Universal characteristics of the unit emission of NOx[8]

\section{Ship's propulsion model}

The mathematical relationship between the individual model blocks is illustrated in Fig. 5. This is a onedimensional model. It is based on two basic integrating blocks (A and B blocks). These blocks in the simulation model convert data from nodes to the unit's progressive velocity and rotational speed of the drive system. The linear velocity of a ship is calculated by integrating a difference between a propeller thrust forces and total resistance of a hull in simulating time. It is made by block B.

Using the second principle of Newton's dynamics, obtained [7]:

$$
\frac{\mathrm{d}(\mathrm{D} \cdot \mathrm{v})}{\mathrm{dt}}=(\mathrm{T}-\mathrm{R})
$$


where: D - displacement of a ship [kg], v - speed of a ship $[\mathrm{m} / \mathrm{s}], \mathrm{T}-$ propeller thrust $[\mathrm{N}], \mathrm{R}$ - total hull resistance [N].

After integration on both sides, equations (1) were obtained:

$$
\mathrm{v}=\int \frac{1}{\mathrm{D}}(\mathrm{T}-\mathrm{R}) \mathrm{dt}+\mathrm{v}_{0}
$$

where: $\mathrm{v}_{0}$ - initial speed of the ship [m/s].

The calculated linear velocity stays in the loop and returns to the block calculating the resistance of a hull. Block A calculates the rotational speed of a drive shaft. After reusing the second Newton's dynamics principle [7]:

$$
\frac{\mathrm{d}(2 \cdot \pi \cdot \mathrm{I} \cdot \mathrm{n})}{\mathrm{dt}}=(\mathrm{M}-\mathrm{Q})
$$

where: I - moment of inertia $\left[\mathrm{kg} \cdot \mathrm{m}^{2}\right], \mathrm{n}$ - rotation speed $[1 / \mathrm{s}], \mathrm{M}-$ engine torque $[\mathrm{N} \cdot \mathrm{m}], \mathrm{Q}-$ propeller torque $[\mathrm{N} \cdot \mathrm{m}]$.

Integrating the equation (3) on both sides:

$$
\mathrm{n}=\int \frac{1}{2 \cdot \pi \cdot \mathrm{I}}(\mathrm{M}-\mathrm{Q}) \mathrm{dt}+\mathrm{n}_{0}
$$

where: $\mathrm{n}_{0}-$ initial rotation speed $[1 / \mathrm{s}]$.

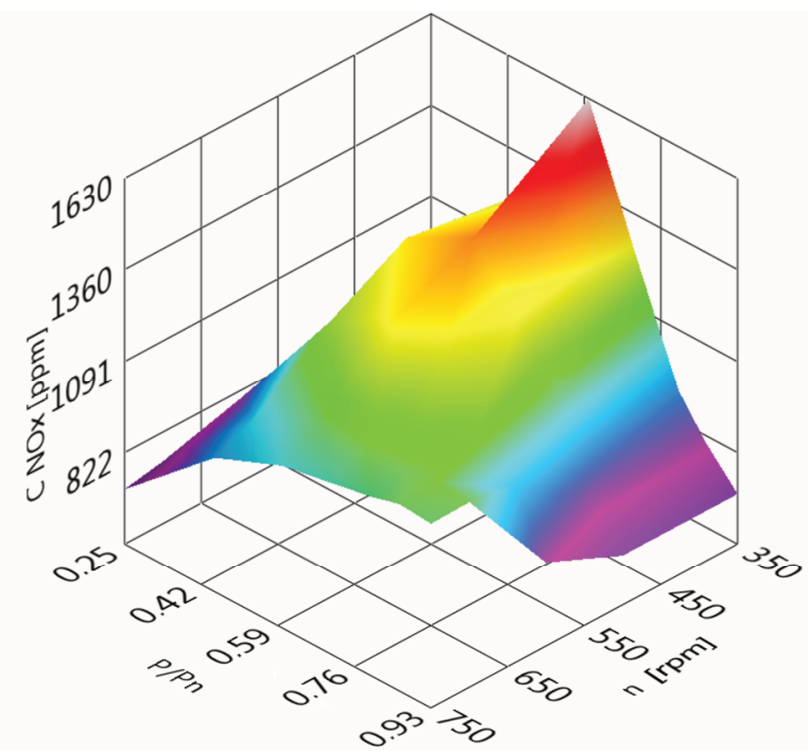

Fig. 4. Concentration $\mathrm{NO}_{\mathrm{x}}$ map

The dependencies 2 and 4 were used as the basis for modelling in the programmatic environment. Figure 6 presents a program based on the Labview environment. In addition, cooperative subprograms have been developed whose mutual relations are necessary to carry out dynamic simulations and they are: hull ("Hull"), gear ("Gear"), ship engine ("Engine") and propeller ("Prop"). As an engine speed controller, the Proportional-Integral-Derivative controller (PID) has been selected, which with appropriate settings of the gain coefficients like proportional $\left(\mathrm{K}_{\mathrm{p}}\right)$, differentiating $\left(\mathrm{K}_{\mathrm{d}}\right)$, integral $\left(\mathrm{K}_{\mathrm{i}}\right)$ is to simulate the ship's governor. It is possible to set (reference) the rotational speed of a propulsion system, which the PID controller used to maintain. The governor controls an engine via a fuel rack (modifying the fuel dose supplied to engine cylinders), making an appropriate correction ensuring constant engine speed, which was also used in the model. The result of calculations made with the help of an "Engine" subprogram is a torque, which then goes to a gear subprogram ("Gear"). Due to the set transmission ratio (in this case 1:2), the torque value increases at a expense of a marine engine. The results obtained in the simulation form the basis for calculations in the block propeller "Prop", while the value of the gear's torque returns to the sum node. As a result of the "Prop" subprogram calculation, receives the propeller torque (goes to the sum node) and the thrust force of the propeller (goes to the next summation node calculating the difference with the total resistance of the hull). In the subprogram "Hull" the total resistance of a hull is calculated depending on speed of a ship [3]:

$$
\mathrm{R}=\sum_{\mathrm{i}} \mathrm{R}_{(\mathrm{i})}=\mathrm{R}_{\mathrm{F}}+\mathrm{R}_{\mathrm{VP}}+\mathrm{R}_{\mathrm{W}}+\mathrm{R}_{\mathrm{D}}
$$

where: $R_{F}$ - friction resistance $[N], R_{V P}-$ shape resistance $[N], R_{W}$ - wave resistance $[N], R_{d}$ - remaining resistance $[\mathrm{N}]$.

The propeller computational algorithm uses the approximations of a propeller B-series with a fixed pitch from the Wageningen research institute. The derived Wageningen polynomials determine a propeller torque and thrust coefficients depending on the blade number, propeller pitch, diameter, expanded area and advance coefficient, also taking into account the Reynolds number [1].

$$
\begin{aligned}
& K_{T}=f_{T}\left(J, \frac{P}{D_{p}}, \frac{A_{E}}{A_{0}}, Z, R_{e}, \frac{t}{c}\right) \\
& K_{Q}=f_{Q}\left(J, \frac{P}{D_{p}}, \frac{A_{E}}{A_{0}}, Z, R_{e}, \frac{t}{c}\right)
\end{aligned}
$$

where: $\mathbf{J}$ - advance coefficient, $\mathrm{P}$ - propeller pitch, $\mathrm{D}_{\mathrm{p}}-$ propeller diameter, $A_{E}$ - expanded area, $A_{0}$ - disc area, $Z$ blade number, $\mathrm{R}_{\mathrm{e}}-$ Reynolds number, $\mathrm{t} / \mathrm{c}$ - blade thickness coefficient.

Figures 9-10 presents results of simulation of concentrations of harmful compounds for the SULZER marine engine type 6AL20/2, which has been implemented in a simulated propulsion system with a fixed pitch screw.

Technical data of the ship used in the simulation were adopted as follows:

- displacement $-300 \mathrm{t}$,

- total length $-35 \mathrm{~m}$,

- breadth $-8 \mathrm{~m}$,

- draught $-3 \mathrm{~m}$,

- propeller diameter $-1.5 \mathrm{~m}$,

- blade number -4 ,

- P/D coefficient - 1.4,

- propeller expanded area $-1.8 \mathrm{~m}^{2}$.

Simulation of concentrations of harmful compounds was carried out during the acceleration of the ship from 0 to 7 knots.

\section{Summary}

The simulation model of the marine propulsion system presented in the article is the basis for the development of a model of emission of harmful compounds in dynamic change of load. It is based on emission maps that are necessary to simulate concentrations of harmful compounds. Further development of the program will include a more detailed refinement of the model using neural networks and 


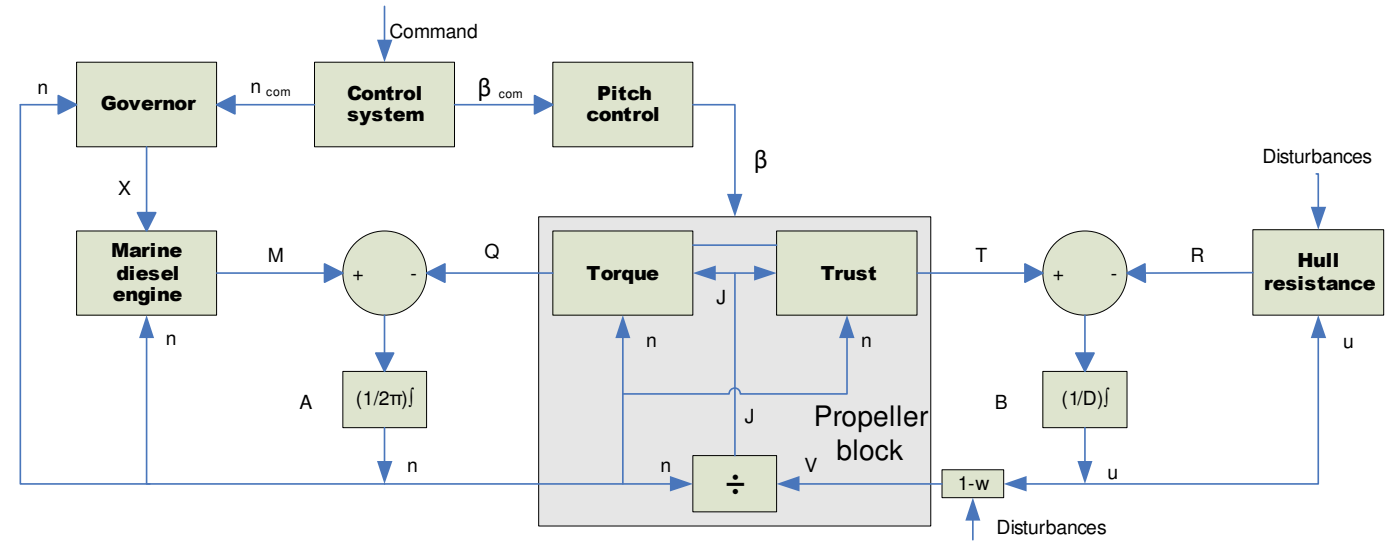

Fig. 5. Block diagram of a ship's propulsion system [6]

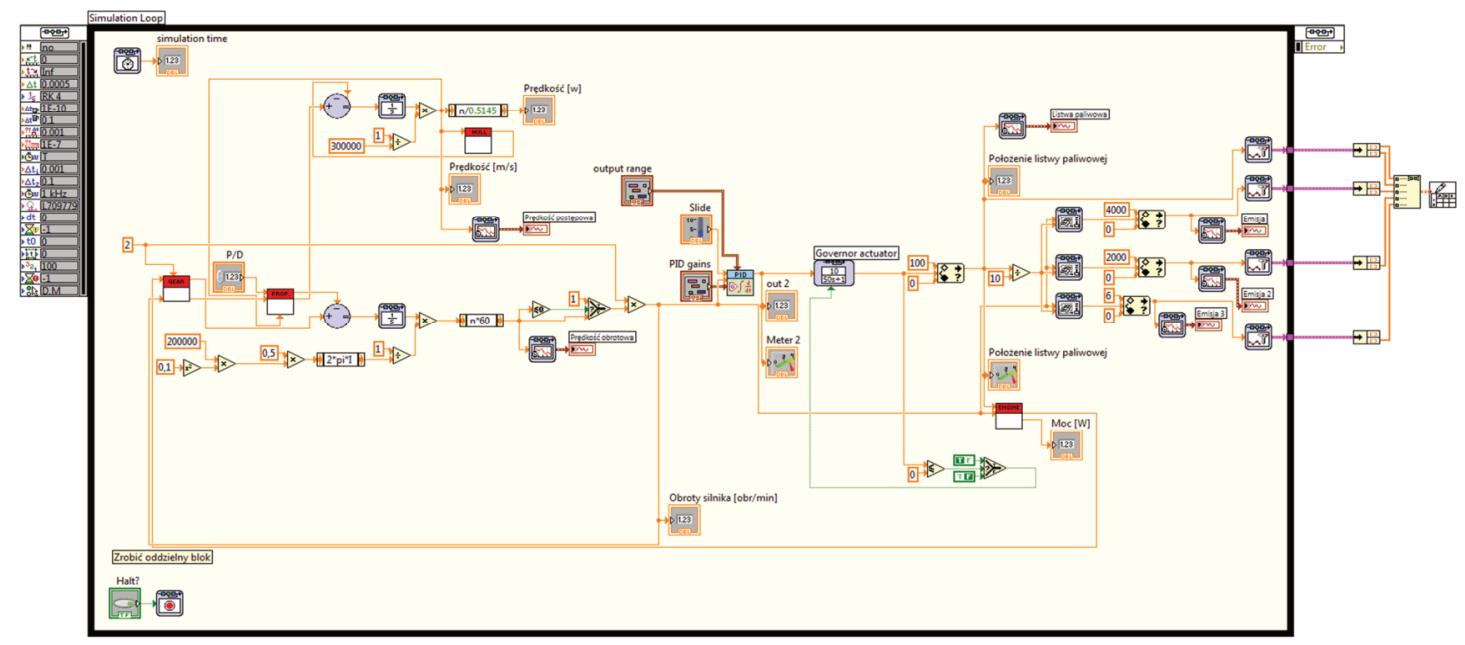

Fig. 6. Simulation model of a ship's propulsion in the Labview environment

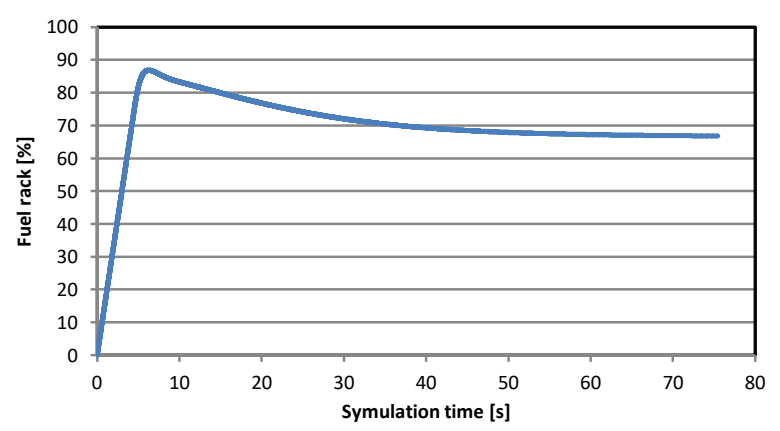

Fig. 7. Position of fuel rack during simulation

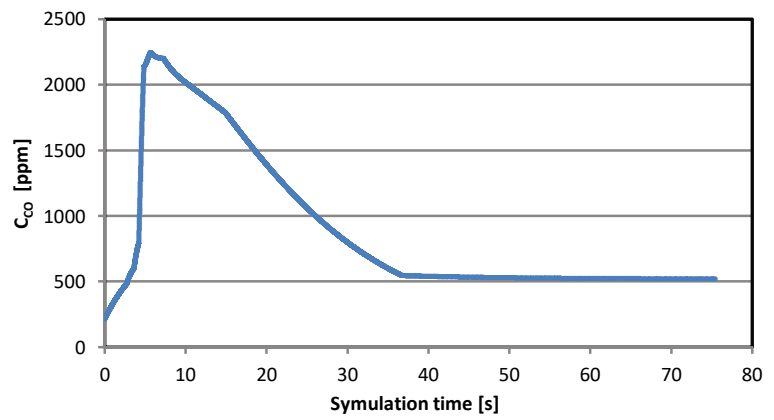

Fig. 8. Concentration of carbon monoxide during simulation

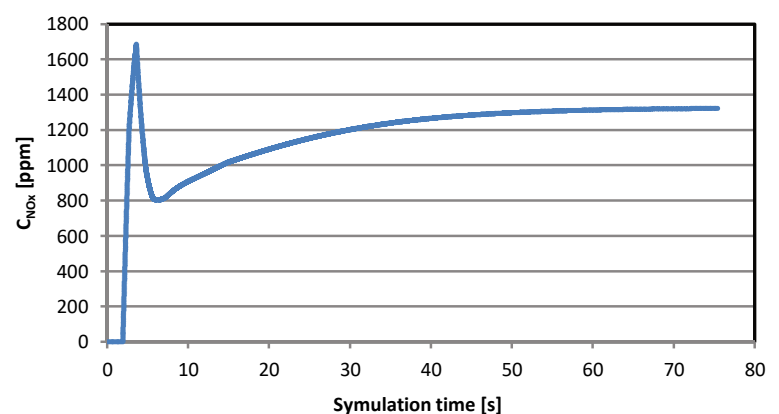

Fig. 9. Concentration of nitrogen oxides during simulation

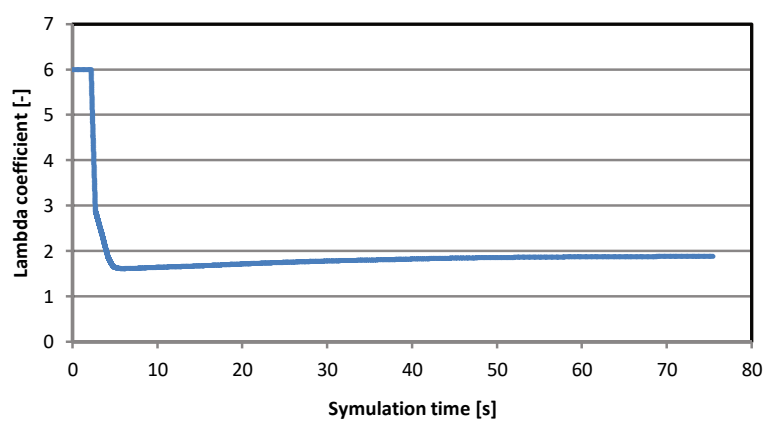

Fig. 10. Lambda coefficient during simulation 
weather modules in the form of changing weather conditions (wind strength) and sea states. It would also be advisable to evaluate its adherence based on a comparison of the experimental results of a laboratory engine and an engine in a marine propulsion system of a real marine vessel operated in sea conditions during a dynamic change of load due to port maneuvers or maneuvers closely related to the purpose of a ship, for example, a salvage ship putting an anchorage for diving work.

\section{Bibliography}

[1] CARLTON, J. Marine Propellers and Propulsion. $M P G$ Books Ltd.

[2] CHRUŚCIEL, M. Labview w praktyce. Wydawnictwo BTC. Legionowo 2008.

[3] KNIAZIEWICZ, T. Modelowanie procesów emisji spalin okrętowych tłokowych silników spalinowych napędu głównego w rzeczywistych warunkach eksploatacji. Zeszyty naukowe AMW. Gdynia 2013.

[4] MARIN, Sea shipping emission 2014. Final report. Bilthoven Netherlands 2016.

Tomasz Kniaziewicz, DSc., DEng. - Faculty of Mechanical and Electrical Engineering, Polish Naval Academy.

e-mail: t.kniaziewicz@amw.gdynia.pl
[5] MERKISZ, J., PIASECZNY, L., KNIAZIEWICZ, T. Zagadnienia emisji spalin silników okrętowych. Wydawnictwo Politechniki Poznańskiej. Poznań 2016.

[6] PIASECZNY, L. Metody wyznaczania statycznych i dynamicznych charakterystyk emisji związków toksycznych z silników spalinowych statków morskich. Sprawozdanie z projektu badawczego N509 572 839. AMW Gdynia 2013.

[7] SCHULTEN, P. The interaction between diesel engines, ship and propellers during . manoeuvring. DUP science is an imprint of Delft University Press. Delft 2005.

[8] WOJNOWSKI, W. Okrętowe siłownie spalinowe. AMW Gdynia 1998.

Artur Bogdanowicz, MEng. - Faculty of Mechanica and Electrical Engineering, Polish Naval Academy.

e-mail: a.bogdanowicz@amw.gdynia.pl
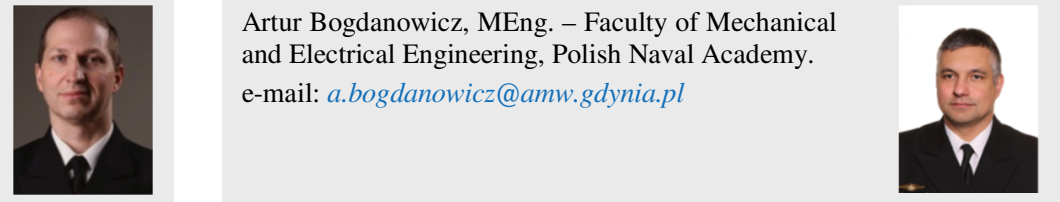